\title{
Lubiprostone Increases Small Intestinal Smooth Muscle Contractions Through a Prostaglandin E Receptor 1 (EP 1 )-mediated Pathway
}

\author{
Walter W Chan ${ }^{1,2}$ and Hiroshi Mashimo $0^{1,2,3 *}$ \\ ${ }^{1}$ Division of Gastroenterology, Hepatology and Endoscopy, Brigham and Women's Hospital, Boston, MA, USA; ${ }^{2}$ Harvard Medical School, \\ Boston, MA, USA; and ${ }^{3}$ Division of Gastroenterology, VA Boston Health System, Boston, MA, USA
}

\begin{abstract}
Background/Aims
Lubiprostone, a chloride channel type 2 (CIC-2) activator, was thought to treat constipation by enhancing intestinal secretion. It has been associated with increased intestinal transit and delayed gastric emptying. Structurally similar to prostones with up to $54 \%$ prostaglandin $E_{2}$ activity on prostaglandin $E$ receptor $1\left(E_{1}\right)$, lubiprostone may also exert $E P_{1}$-mediated procontractile effect on intestinal smooth muscles. We investigated lubiprostone's effects on intestinal smooth muscle contractions and pyloric sphincter tone.
\end{abstract}

\section{Methods}

Isolated murine small intestinal (longitudinal and circular) and pyloric tissues were mounted in organ baths with modified Krebs solution for isometric recording. Basal muscle tension and response to electrical field stimulation (EFS; 2 ms pulses/10 $\mathrm{V} / 6 \mathrm{~Hz} / 30 \mathrm{sec}$ train) were measured with lubiprostone $\left(10^{-10}-10^{-5} \mathrm{M}\right) \pm E P_{1}$ antagonist. Significance was established using Student $t$ test and $P<0.05$.

\section{Results}

Lubiprostone had no effect on the basal tension or EFS-induced contractions of longitudinal muscles. With circular muscles, lubiprostone caused a dose-dependent increase in EFS-induced contractions $(2.11 \pm 0.88$ to $4.43 \pm 1.38 \mathrm{~N} / \mathrm{g}, P=0.020)$ that was inhibited by pretreatment with $E P_{1}$ antagonist $(1.69 \pm 0.70$ vs. $4.43 \pm 1.38 \mathrm{~N} / g, P=0.030)$. Lubiprostone had no effect on circular muscle basal tension, but it induced a dose-dependent increase in pyloric basal tone (1.07 \pm 0.01 to $1.97 \pm 0.86$ fold increase, $P<0.05)$ that was inhibited by $E P_{1}$ antagonist.

\section{Conclusions}

In mice, lubiprostone caused a dose-dependent and $\mathrm{EP}_{1}$-mediated increase in contractility of circular but not longitudinal small intestinal smooth muscles, and in basal tone of the pylorus. These findings suggest another mechanism for lubiprostone's observed clinical effects on gastrointestinal motility.

(J Neurogastroenterol Motil 2013;19:312-318)

Key Words

Gastrointestinal motility; Intestine, small; Lubiprostone; Receptors, prostaglandin E

Received: February 2, 2013 Revised: April 18, 2013 Accepted: April 19, 2013

(c) This is an Open Access article distributed under the terms of the Creative Commons Attribution Non-Commercial License (http://creativecommons. org/licenses/by-nc/3.0) which permits unrestricted non-commercial use, distribution, and reproduction in any medium, provided the original work is properly cited.

*Correspondence: Hiroshi Mashimo, MD, PhD

Division of Gastroenterology, VAMC/Harvard Res 151, 1400 VFW Parkway, West Roxbury, MA 02132, USA

Tel: +1-857-203-5640, Fax: +1-857-203-5666, E-mail: hmashimo@hms.harvard.edu

Financial support: This work was supported by VA Boston Healthcare and VA Merit Award (grant to Hiroshi Mashimo).

Conflicts of interest: None (Walter W Chan received the American Neurogastroenterology and Motility Society Young Investigator Award to present this work at the 2009 Neurogastroenterology and Motility Joint Meeting).

Author contributions: Walter W Chan performed the research, analyzed the data and wrote the paper. Hiroshi Mashimo designed the research study, contributed the essential reagents and tools, analyzed the data and wrote the paper. 


\section{Introduction}

Lubiprostone, a chloride channel type 2 (ClC-2) activator, has been approved for the treatment of chronic constipation and constipation-predominant irritable bowel. Prior clinical study performed in healthy volunteers showed that lubiprostone is associated with increased intestinal transit, increased fasting gastric volume and delayed gastric emptying. ${ }^{1}$ The proposed primary mechanism of action of lubiprostone in the gastrointestinal tract is increased chloride ion transport into the intestinal lumen caused by opening of $\mathrm{ClC}-2$, leading to increased intestinal secretion and enhanced mass transit. ${ }^{2,3}$ Nausea is the most common side effect of lubiprostone, reported in up to $31 \%$ of patients in one study. Several possible explanations for nausea have been suggested, including delayed gastric emptying, small intestinal distention secondary to increased gastric secretion, change in gastrointestinal sensation, or additional actions of lubiprostone on gastrointestinal motility. ${ }^{1}$ However, the underlying mechanism of nausea associated with lubiprostone remains unclear. In addition, lubiprostone has been shown to accelerate overall colonic transit without significantly changing the rate of ascending colon emptying. ${ }^{2}$ With the proximal colon likely reabsorbing the increased fluid load from the small intestine, it was postulated that a primary motor effect on the colon beyond the ascending portion may be responsible for this finding. Similarly, the presence of any possible direct smooth muscle effect of lubiprostone on the rest of the gastrointestinal tract has been suggested. In fact, a recent study has shown that lubiprostone increased contraction of rat and human stomach longitudinal muscle, an action that was inhibited by prostaglandin E receptor $1\left(\mathrm{EP}_{1}\right)$ antagonist. ${ }^{6}$ Such effects may also be responsible for the clinical effect of lubiprostone such as nausea seen in humans.

Although lubiprostone is structurally similar to prostone, a bicyclic fatty acid compound derived from prostaglandin $\mathrm{E}_{1}$ $\left(\mathrm{PGE}_{1}\right)$ its level of interaction with E-type prostanoid receptors and the possible resultant clinical effect are not completely clear. While prior studies have suggested that lubiprostone only has very weak activity on prostaglandin receptors, it has also been reported to have up to $54 \% \mathrm{PGE}_{2}$ activity on $\mathrm{EP}_{1}{ }^{7}$ Recent studies have suggested that lubiprostone may also exert prostaglandin effects on non-gastrointestinal tissues. ${ }^{8}$ Given lubiprostone's structural similarity to prostone, reported activity on $\mathrm{EP}_{1}$, and effect on intestinal transit, we postulated that it may have direct procontractile effects on both phasic and tonic smooth muscles in the small intestine, possibly involving $\mathrm{EP}_{1}$ activation. In this study, we investigated the effect of lubiprostone on the basal tone and neuronally-stimulated contraction of the phasic intestinal smooth muscle and the tonic pyloric sphincter muscle in mice. We also studied the possible interaction of lubiprostone on $\mathrm{EP}_{1}$ using a specific antagonist.

\section{Materials and Methods}

\section{Tissue Isolation and Preparation}

Ten adult wild-type mice were sacrificed by carbon dioxide asphyxiation followed by cervical dislocation. All efforts were made to minimize the number of animals used. Immediately after death of the mice, a midline incision was made exposing the peritoneal cavity and contents. The stomach and entire small intestine were excised. The tissues were placed immediately in a pre-mixed Krebs solution ( $118 \mathrm{mM} \mathrm{NaCl}, 4.8 \mathrm{mM} \mathrm{KCI}, 1.2 \mathrm{mM} \mathrm{KH}_{2} \mathrm{PO}_{4}$, $1.2 \mathrm{mM} \mathrm{MgSO}_{4}, 2.5 \mathrm{mM} \mathrm{CaCl}_{2}, 25 \mathrm{mM} \mathrm{NaHCO}_{3}$ and 11 $\mathrm{mM}$ glucose), which was previously equilibrated with $5 \% \mathrm{CO}_{2}$ in $\mathrm{O}_{2}$ at a temperature of $37^{\circ} \mathrm{C}$. The pylorus was isolated and $1 \mathrm{~cm}$ transverse sections of the small intestine were obtained. The mucosa was left intact. The tissues were thoroughly flushed with the Krebs solution to remove any remaining food or bile.

For small intestine, longitudinal muscles were isolated by using $1 \mathrm{~cm}$ length segments of small intestinal tissues. Both ends of the longitudinal muscles were attached to ring clips that were mounted on the isometric force transducers. For circular smooth muscles, the small intestinal tissues were cut into smaller transverse segments of $0.2-0.3 \mathrm{~cm}$ width. The muscle ring prep was then mounted on the force transducers allowing measurement of circular muscle contraction. The pyloric tissues were similarly mounted in a ring prep fashion of approximately $0.5 \mathrm{~cm}$ in width for measurement of basal tone.

\section{Tissue Bath Experiment}

Isolated small intestinal (longitudinal and circular) and pyloric sphincter tissues were mounted in $5 \mathrm{~mL}$ organ baths with Krebs solution for isometric recording. The Krebs solution was maintained in the organ baths by bubbling with $5 \% \mathrm{CO}_{2} / 95 \% \mathrm{O}_{2}$ at $37^{\circ} \mathrm{C}$. Isometric force transducers measured changes in muscle tension of the tissues. Tissue samples were suspended under 4 $\mathrm{mN}$ tension for isometric recording between 2 platinum ring electrodes. This preload was noted to be in the appropriate range of optimal electrical field stimulation (EFS)- and carbachol-in- 
duced contractions. The EFS parameters were chosen from prior experiments ${ }^{9}$ that demonstrated tetrodotoxin-inhibitable neurogenic responses. For this experiment, peak contraction responses were achieved using 30 seconds train of biphasic square-wave pulses of $2 \mathrm{~ms}$ pulse width at 10 volts and frequency of $6 \mathrm{~Hz}$. Baseline measurement was then taken with EFS stimulation in the absence of lubiprostone. Sequential addition of escalating doses of lubiprostone $(0.0001-10 \mu \mathrm{M})$ was then performed to construct a cumulative concentration-response curve for neuronally-stimulated smooth muscle contraction. Similar lubiprostone concentration-response curve for EFS-stimulated smooth muscle contraction was constructed in the presence of $\mathrm{EP}_{1}$ antagonist (SC19220; Sigma, Saint Louis, MO, USA) to evaluate the involvement of the $\mathrm{EP}_{1}$ cascade in the lubiprostone-mediated smooth muscle contraction response.

In a separate set of experiments, the basal tone of the smooth muscle of small intestines and the pylorus were studied in the absence of EFS. By similarly suspending tissue samples under 4 $\mathrm{mN}$ for isometric recording in $5 \mathrm{~mL}$ wells of bubbling Krebs solution, the basal muscle tone of the muscles in response to escalating concentration of lubiprostone were recorded. At the end of the experiment, the tissues were placed on a slide and dried in an oven for obtaining dry weight. Tension measurements were normalized for the mass of tissue.

\section{Data Acquisition and Analysis}

Data acquisition and analysis was performed using the LabChart v. 7.0 software (ADInstruments, Colorado Springs, CO, USA). In the EFS experiments, the difference between the maximal muscle tension post-EFS stimulation and the minimal muscle tension pre-EFS stimulation was calculated for baseline and each lubiprostone concentration. This change in muscle tension pre- and post-EFS stimulation represents the EFS-medi-

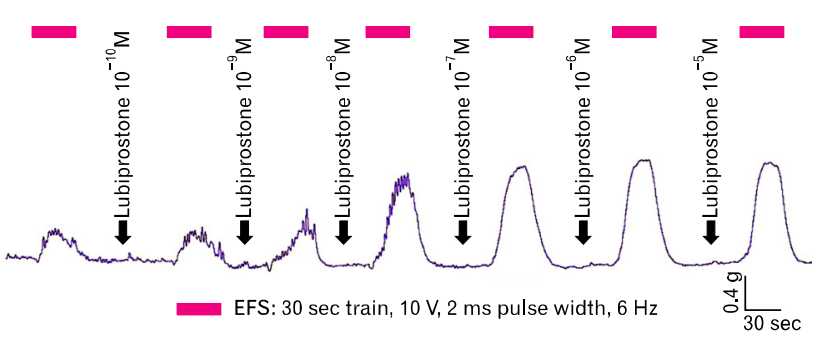

Figure 1. Sample tracing demonstrating increasing electrical field stimulation-induced contractions of intestinal circular smooth muscle with increasing concentrations of lubiprostone. EFS, electrical field stimulation. ated pro-contractile response. In experiments for basal tone without the use of EFS, the maximal muscle tension reached with each lubiprostone concentration was used. The muscle tension was normalized for the dry weight of the tissue used in each experiment. All data are expressed as means \pm standard error of mean. Statistical significance was established using two-tailed Student's $t$ test and $P<0.05$.

\section{Chemical Reagents Used}

All drugs were freshly prepared before use. Lubiprostone was extracted using a 24 gauge needle directly from commercially available 24 microgram capsules and suspended in $100 \%$ ethanol solution. Different concentrations of lubiprostone were obtained by further dilution with $100 \%$ ethanol. The $\mathrm{EP}_{1}$ antagonist (SC19220; Sigma) was dissolved in pre-synthesized Krebs solution.

\section{Ethical Approval}

This study was approved by the VA Health System Institutional Animal Care and Use Committee prior to inception of this investigation.

\section{Results}

\section{Circular Muscles}

In the measurement of EFS-stimulated smooth muscle contractions, lubiprostone induces a dose-dependent increase in cir-

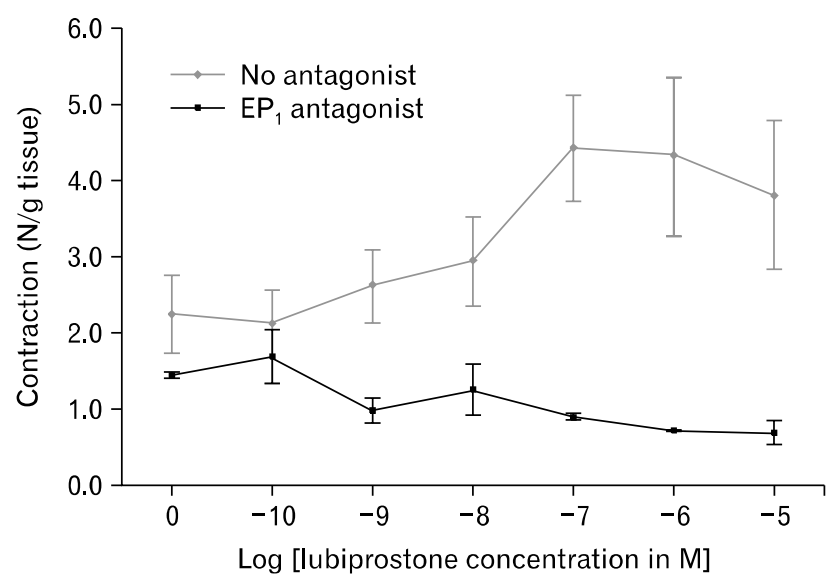

Figure 2. Electrical field stimulation induced contractions of the circular smooth muscle demonstrated a dose-response relationship with increasing concentrations of lubiprostone (no antagonist). The addition of the prostaglandin $\mathrm{E}$ receptor $1\left(\mathrm{EP}_{1}\right)$ antagonist, $\mathrm{SC} 19220$, attenuated the lubiprostone-induced response in muscle contractions. EFS, electrical field stimulation. 
cular muscle contraction (range: $2.11 \pm 0.88 \mathrm{~N} / \mathrm{g}$ tissue to 4.43 $\pm 1.38 \mathrm{~N} / \mathrm{g}$ tissue, $\mathrm{n}=5, P=0.020)$. Pretreatment with $1 \mu \mathrm{M}$ $\mathrm{EP}_{1}$-RA SC19220 inhibits the enhanced circular muscle contraction induced by lubiprostone $(4.43 \pm 1.38 \mathrm{~N} / \mathrm{g}$ tissue at 10 $\mu \mathrm{M}$ lubiprostone vs. $1.69 \pm 0.70 \mathrm{~N} / \mathrm{g}$ tissue with $\mathrm{EP}_{1}$ antagonist, $P=0.030$ ) (Fig. 1 and 2). The addition of SC19220 alone without lubiprostone did not result in any significant difference in EFS-stimulated circular muscle contraction from baseline. This suggests that the observed antagonistic effect of SC19220 on lubiprostone action was not due to a direct effect of SC19220 on muscle contraction. No effect was observed of lubiprostone on the basal tension of the circular muscles, as the basal muscle tension remained the same despite increasing concentrations of lubi-

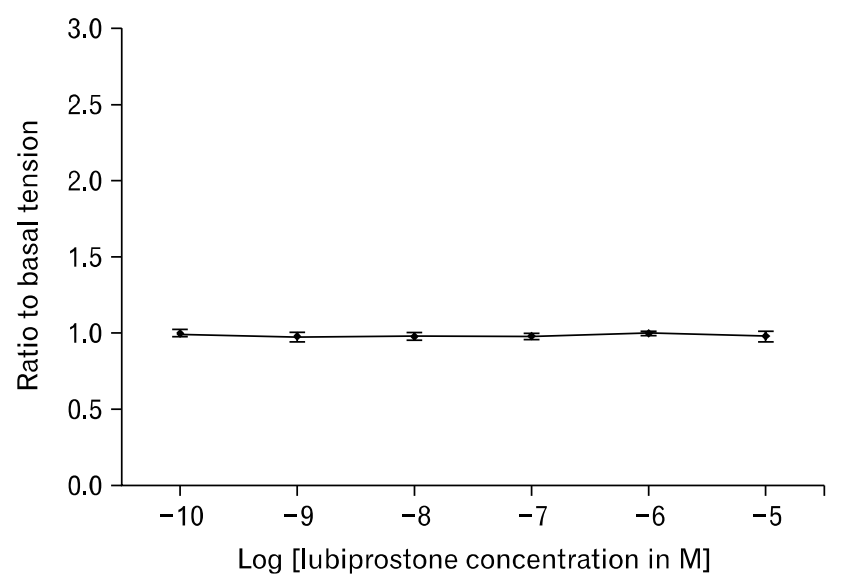

Figure 3. Basal circular smooth muscle tone of the small intestine did not show any significant differences with increasing concentrations of lubiprostone.

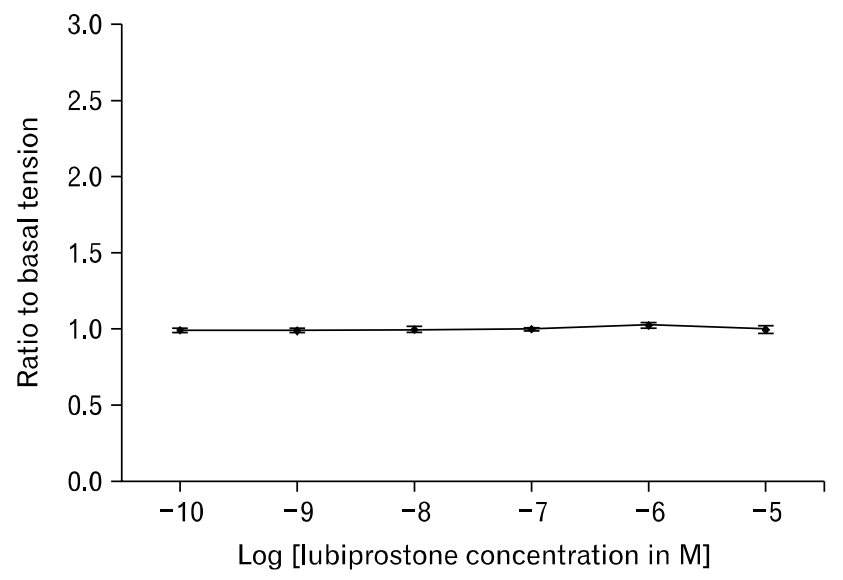

Figure 4. Longitudinal smooth muscle tone of the small intestine demonstrated no significant changes with increasing concentrations of lubiprostone. prostone (range: 0.96 to 0.99 times baseline muscle tension, $P=$ $0.95)$ (Fig. 3).

\section{Longitudinal Muscles}

In the study of small intestinal longitudinal muscles, adding lubiprostone exerted no effect on the basal muscle tension. The muscle tension measured at incremental concentrations of lubiprostone ranged from 0.99 to 1.03 times of muscle tension at base-

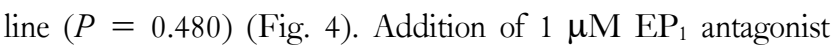
SC19220 also induced no change in the muscle tension measured. Stimulation of smooth muscle contraction by EFS with increasing concentrations of lubiprostone yielded similar results, with the measured contractions ranging from $0.91 \pm 0.46 \mathrm{~N} / \mathrm{g}$ tissue to $1.10 \pm 0.57 \mathrm{~N} / \mathrm{g}$ tissue $(\mathrm{n}=5, P=0.998)$ (Fig. 5).

\section{Pyloric Sphincter}

The basal tone of the pyloric sphincter $(n=5)$ demonstrated dose-dependent increase with the addition of escalating doses of lubiprostone (range: $1.07 \pm 0.01$ to $1.97 \pm 0.96$ times baseline tension, $P<0.01)$. Pretreatment with $1 \mu \mathrm{M} \mathrm{EP} \mathrm{EP}_{1}$ antagonist SC19220 inhibits the enhanced pyloric tone induced by lubiprostone $(1.97 \pm 0.96$ times baseline tension at $10 \mu \mathrm{M}$ lubiprostone vs. $1.16 \pm 0.09$ times baseline tension with $\mathrm{EP}_{1}$ antagonist, $P<$ 0.01) (Fig. 6).

\section{Discussion}

Lubiprostone is a $\mathrm{PGE}_{1}$ derivative which has been approved for the treatment of chronic constipation and constipation-pre-

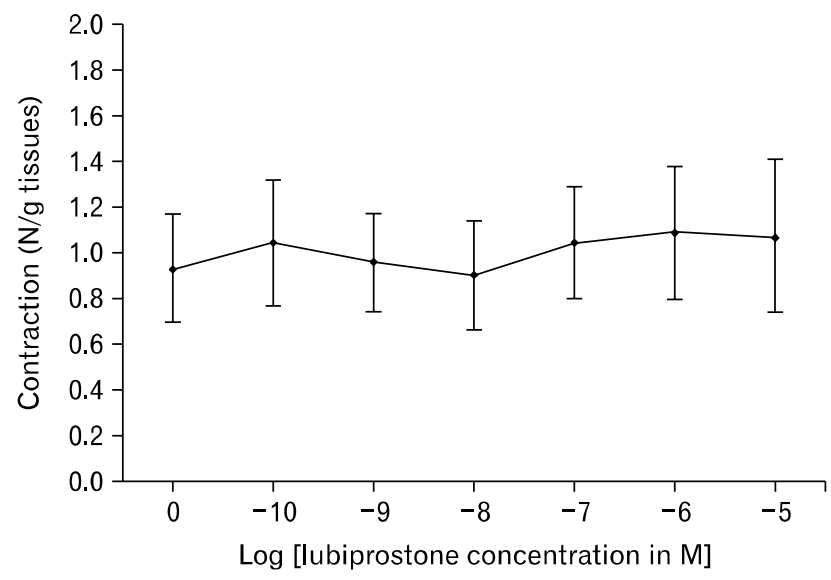

Figure 5. Neuronal contractions of the longitudinal smooth muscles as simulated by electrical field stimulation showed no response to increasing concentrations of lubiprostone. 


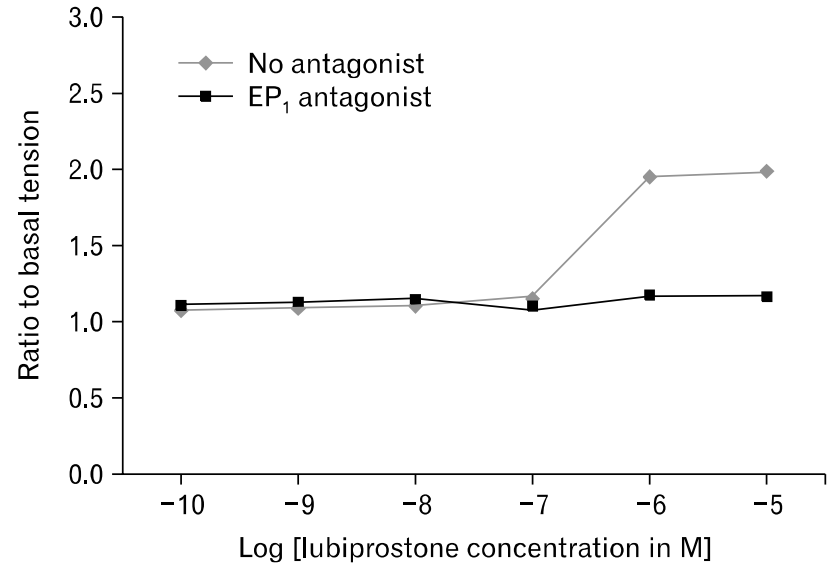

Figure 6. The pyloric sphincter tone revealed a mild, significant increase in basal tone with lubiprostone. This increase in tone was inhibited by the prostaglandin E receptor $1\left(\mathrm{EP}_{1}\right)$ antagonist SC19220.

dominant irritable bowel. Its proposed primary mechanism of action is an increase in chloride ion transport into the intestinal lumen caused by opening of the novel $\mathrm{ClC}-2$ chloride channels, leading to increased intestinal secretion and enhanced mass transit. One of the promoted characteristics of lubiprostone is its specificity for $\mathrm{ClC}-2$ and lack of systemic prostaglandin effects, despite its structural similarity to prostones. As shown in previously published studies, activation of E-type prostanoid receptors by PGE is associated with smooth muscles contractions in the gastrointestinal tract. The structural similarity of lubiprostone to $\mathrm{PGE}_{1}$ and the known procontractile action of $\mathrm{PGE}_{1}$ on certain smooth muscles led us to hypothesize that lubiprostone may also have direct gastrointestinal smooth muscle actions contributing to its clinical effects.

Our study has focused on the study of small intestinal and pyloric sphincter smooth muscles, 2 physiologically different types of smooth muscle. Small intestinal longitudinal and circular muscles are both phasic muscle. Phasic contractions are characterized by rapid contraction and relaxation. Rhythmic phasic contractions of intestinal smooth muscle generate peristalses that propel food through the gastrointestinal tract. On the other hand, the pyloric sphincter is an example of tonic muscle. Contrary to phasic contractions, tonic contractions are slow and sustained. Relaxation of the sustained tonic contractions leads to the opening of the sphincter that allows passage of chyme from stomach to the duodenum. Lubiprostone may exert different effects on the various types of smooth muscles, resulting in the clinical profile of the medication.
As lubiprostone treats constipation by reducing intestinal transit time, we hypothesized that it may also have a procontractile effect on the phasic intestinal smooth muscles. Using EFS to simulate neuronal stimulation, our study demonstrated that lubiprostone indeed increases the circular smooth muscle contractions in a dose-dependent manner, while it has no effect on the longitudinal muscles. The disparity in the response of these muscles is consistent with the known mechanism of propulsion of intestinal contents, which requires coordinated but reciprocal activities of longitudinal and circular muscles during peristalsis. ${ }^{10}$ With each peristalsis, circular muscles contract oral and relax caudal to the site of stimulation, and longitudinal muscles contract and relax in reverse to circular muscles to provide the coordinated forward propulsion. Therefore, longitudinal muscles exert ascending relaxation and descending contraction with each peristalsis. With these physiological properties of intestinal smooth muscles, our results can explain another mechanism for the accelerated intestinal transit caused by lubiprostone besides the volume transit through its effect on $\mathrm{ClC}-2$. The enhancement of contractions in one type of muscles (circular) coupled with the lack of effect in the other (longitudinal) by lubiprostone could result in stronger forward propulsive force.

Our study has also shown that the procontractile effect on circular smooth muscle tension observed may have been achieved through an $\mathrm{EP}_{1}$-mediated pathway, as pretreatment with an $\mathrm{EP}_{1}$ antagonist attenuated the procontractile effect of lubiprostone. Previous studies have demonstrated that $\mathrm{PGE}_{2}$ and its different receptor subtypes exert varying effects on gastrointestinal motility. ${ }^{11,12}$ In particular, in a study of circular smooth muscles isolated from pig and guinea-pig ileum, $\mathrm{EP}_{1}$ agonist enhances contraction of the muscle cells. ${ }^{11} \mathrm{EP}_{1}$ are $\mathrm{G}$ protein-coupled receptors that regulate $\mathrm{Ca}^{2+}$-channel gating ${ }^{13}$ and they have been shown to increase $\mathrm{Ca}^{2+}$ concentration in Chinese hamster ovary cells without detectable phosphatidylinositide response. ${ }^{14}$ Enhanced smooth muscle contractions, therefore, may be induced by $\mathrm{EP}_{1}$ via changes in intracellular $\mathrm{Ca}^{2+}$ concentrations of smooth muscle cells. While different subtypes of $\mathrm{PGE}_{2}$ receptors are present in varying concentrations throughout the gastrointestinal tract, $\mathrm{EP}_{1}$ have been detected in the muscularis mucosa, enteric glial cells, and smooth muscle layers of the small intestine. ${ }^{15-17}$ Therefore, the increased muscular contractions by lubiprostone could be a result of effects on muscle or glial cells. Prior studies have suggested roles for enteric glial cells in neurotransmission by mediating intercellular $\mathrm{Ca}^{2+}$ waves ${ }^{18}$ and muscular contraction by increasing intracellular $\mathrm{Ca}^{2+}$ concentration. ${ }^{19}$ Clinical studies of pa- 
tients with severe, chronic, slow-transit constipation demonstrate a loss of enteric glial cells and interstitial cells of Cajal, ${ }^{20}$ but the specific roles of these cells in $\mathrm{EP}_{1}$-mediated contraction remains poorly characterized. The lubiprostone-mediated increase in circular muscle contractions during EFS observed in this study may have resulted from activation of $\mathrm{EP}_{1}$ located on either muscle or enteric glial cells.

In the study of pyloric muscles, lubiprostone increased the basal tone of the pyloric sphincter in a dose-dependent manner. This procontractile effect was attenuated by pretreatment with an $\mathrm{EP}_{1}$ antagonist, suggesting that the lubiprostone acted through an $\mathrm{EP}_{1}$-mediated pathway. Prior studies have demonstrated the presence of $\mathrm{EP}_{1}$ in the mucosal and smooth muscle layers of the gastric body and antrum. ${ }^{15,16}$ However, the existence of $\mathrm{EP}_{1}$ or other $\mathrm{PGE}_{2}$ receptors in the pylorus remains unclear. Our results demonstrated the likely presence of $\mathrm{EP}_{1}$ on pyloric tissues and the possible effect of activation of the $\mathrm{EP}_{1}$ pathway. These pharmacologic effects will need to be confirmed on human tissues.

One of the main side effects of lubiprostone is nausea, which may affect up to a third of the patients. The underlying mechanism of lubiprostone-induced nausea is unclear. However, several possible processes have been suggested, including delayed gastric emptying, small intestinal distention from increased gastric secretion, change in gastrointestinal sensation, or alteration of gastrointestinal motility. The elevation of basal pyloric sphincter tone caused by lubiprostone may contribute to the nausea symptoms by delaying gastric emptying or in the form of pylorospasm. The resultant nausea may be particularly pronounced as lubiprostone increases gastric secretion through the activation of chloride channels. Gastric distention from decreased pyloric outflow and increased gastric secretion may produce nausea symptoms, especially in those with decreased compliance of the gastric wall.

Our results are significant in demonstrating prostaglandinlike actions of lubiprostone in the gastrointestinal tract, in addition to its known specific chloride channel effects. It is now less clear whether the clinical effects observed in patients with constipation result predominantly from activation of $\mathrm{ClC}-2$, as formerly believed, or from its prostaglandin-like effects on intestinal smooth muscles. Recent evidence suggests that lubiprostone acts predominantly on the classical cystic fibrosis transmembrane conductance regulator (CFTR), and no chloride secretion could be observed using rectal epithelial cells from a patient homozygous for defective (F580del) CFTR. ${ }^{21}$ In contrast, lubiprostone has been demonstrated in a recent case series to relieve constipation in patients with cystic fibrosis. ${ }^{22}$ Thus the clinical benefit seen in these patients with defective CFTR may be related to lubiprostone's action on $\mathrm{EP}_{1}$, as demonstrated by our results. Therefore, the general mechanisms of lubiprostone in relieving constipation may be multimodal.

Through understanding the underlying mechanism of lubiprostone effects, the newly described pathway of action for lubiprostone may open potential new use for the medication. For example, patients with small intestinal pseudo-obstruction or ileus may respond to the procontractile effects of lubiprostone, while those with bile reflux may improve due to the increase in basal pyloric sphincter tone. This may also enhance bicarbonate secretion and have cytoprotective effects, akin to misoprostol. On the other hand, potential negative consequences of $\mathrm{PGE}_{2}$ receptor activation should also be considered. Previous studies have demonstrated that blockade of $\mathrm{EP}_{1}$ and $\mathrm{EP}_{4}$ inhibits the development of colon cancer in mouse models. ${ }^{23,24}$ Given lubiprostone's demonstrated agonist effect on $\mathrm{EP}_{1}$, its chronic use may result in adverse consequence. Further studies are required to delineate lubiprostone's other potential short- and long-term clinical effects resulting from its prostaglandin-like activities. Orally administered lubiprostone is rapidly metabolized, not only by the liver, but also immediately on the mucosal surface. Thus the intact compound is not detectable in the blood. ${ }^{25}$ Therefore, it is possible that the observed pro-contractile effects of lubiprostone are mediated by its metabolites. Also its primary site of action may be the mucosa, and not necessarily directly on the smooth muscles. To understand lubiprostone's actual clinical effect, we chose to study intact muscle preparation without inhibiting adrenergic or cholinergic effects and without removing the mucosa. Further mechanistic studies discerning its site of action, metabolites, and pathways would be warranted. Its interactions with other $\mathrm{PGE}_{2}$ receptor subtypes should also be explored.

In conclusion, lubiprostone, previously described as a selective chloride channel activator with little prostaglandin effect, caused a dose-dependent and $\mathrm{EP}_{1}$-mediated increase in contractility of circular but not longitudinal small intestinal smooth muscles in mice. It had no effect on the basal tone of these phasic muscles. However, in the tonic pyloric sphincter, lubiprostone caused a dose-dependent increase in basal tone that was attenuated by an $\mathrm{EP}_{1}$ antagonist. These findings suggest potential prostaglandin-like activities of lubiprostone. They also provide another mechanism for the previously-reported accelerated intestinal transit and delayed gastric emptying in normal individuals given lubiprostone. 


\section{References}

1. Camilleri M, Bharucha AE, Ueno R, et al. Effect of a selective chloride channel activator, lubiprostone, on gastrointestinal transit, gastric sensory, and motor functions in healthy volunteers. Am J Physiol 2006;290:G942-G947.

2. Cuppoletti J, Malinowska DH, Tewari KP, et al. SPI-0211 activates T84 cell chloride transport and recombinant human $\mathrm{ClC}-2$ chloride currents. Am J Physiol 2004;287(6 Pt 1):C1173-C1183.

3. Ueno R, Osama H, Habe T, Engelke K, Patchen M. Oral SPI0211 increases intestinal fluid secretion and chloride concentration without altering serum electrolyte levels [abstract]. Gastroenterology 2004;126(suppl 2):A298.

4. Sun X, Wang X, Wang GD, et al. Lubiprostone reverses the inhibitory action of morphine on mucosal secretion in human small intestine. Dig Dis Sci 2011;56:330-338.

5. Hussar DA. New drugs: lubiprostone, ranolazine, and anidulafungin. J Am Pharm Assoc 2006;46:411-414.

6. Bassil AK, Borman RA, Jarvie EM, et al. Activation of prostaglandin EP receptors by lubiprostone in rat and human stomach and colon. Br J Pharmacol 2008;154:126-135.

7. Parentesis GP, Crawford DF, Engelke KJ, Osama H, Ueno R. Effects of lubiprostone, a novel GI chloride channel activator, on isolated smooth muscle [abstract]. Neurogastroenterol Motil 2005;17: 625.

8. Cuthbert AW. Lubiprostone targets prostanoid $\mathrm{EP}_{4}$ receptors in ovine airways. Br J Pharmacol 2011;162:508-520.

9. Kim CD, Goyal RK, Mashimo H. Neuronal NOS provides nitrergic inhibitory neurotransmitter in the mouse lower esophageal sphincter. Am J Physiol 1999;277(2 Pt 1):G280-G284.

10. Grider JR. Reciprocal activity of longitudinal and circular muscle during intestinal peristaltic reflex. Am J Physiol Gastrointest Liver Physiol 2003;284:G768-G775.

11. Botella A, Delvaux M, Fioramonti J, Frexinos J, Bueno L. Stimulatory $\left(\mathrm{EP}_{1}\right.$ and $\left.\mathrm{EP}_{3}\right)$ and inhibitory $\left(\mathrm{EP}_{2}\right)$ prostaglandin $\mathrm{E} 2$ receptors in isolated ileal smooth muscle cells. Eur J Pharmacol 1993;237:131-137.

12. Smida SD, Svensson KM. Inhibition of cyclooxygenase-2 and $\mathrm{EP}_{1}$ receptor antagonism reduces human colonic longitudinal muscle contractility in vitro. Prostaglandins Other Lipid Mediat 2009;88:117121.
13. Sugimoto Y, Narumiya S. Prostaglandin E receptors. J Biol Chem 2007;282:11613-11617.

14. Katoh H, Watabe A, Sugimoto Y, Ichikawa A, Negishi M. Characterization of the signal transduction of prostaglandin E receptor $\mathrm{EP}_{1}$ subtype in cDNA-transfected Chinese hamster ovary cells. Biochim Biophys Acta 1995;1244:41-48.

15. Ding M, Kinoshita Y, Kishi K, et al. Distribution of prostaglandin E receptors in the rat gastrointestinal tract. Prostaglandins 1997;53: 199-216.

16. Morimoto K, Sugimoto Y, Katsuyama M, et al. Cellular localization of mRNAs for prostaglandin $\mathrm{E}$ receptor subtypes in mouse gastrointestinal tract. Am J Physiol Gastrointest Liver Physiol 1997;272(3 Pt 1): G681-G687.

17. Northey A, Denis D, Cirino M, Metters KM, Nantel F. Cellular distribution of prostanoid EP receptors mRNA in the rat gastrointestinal tract. Prostaglandins Other Lipid Mediat 2000;62:145156.

18. Zhang W, Segura BJ, Lin TR, Hu Y, Mulholland MW. Intercellular calcium waves in cultured enteric glia from neonatal guinea pig. Glia 2003;42:252-262.

19. Zhang W, Sarosi G Jr, Barnhart D, Yule DI, Mulholland MW. Endothelin-activated calcium signaling in enteric glia derived from neonatal guinea pig. Am J Physiol 1997;272(5 Pt 1):G1175-G1185.

20. Bassotti G, Villanacci V, Fisogni S, et al. Enteric glial cells and their role in gastrointestinal motor abnormalities: Introducing the neuro-gliopathies. World J Gastroenterol 2007;13:4035-4041.

21. Bijvelds MJ, Bot AG, Escher JC, De Jonge HR. Activation of intestinal $\mathrm{Cl}$ - secretion by lubiprostone requires the cystic fibrosis transmembrane conductance regulator. Gastroenterology 2009;137:976985.

22. O'Brien CE, Anderson PJ, Stowe CD. Use of the chloride channel activator lubiprostone for constipation in adults with cystic fibrosis: a case series. Ann Pharmacother 2010;44:577-581.

23. Kawamori T, Kitamura T, Watanabe K, et al. Prostaglandin E receptor subtype $\mathrm{EP}_{1}$ deficiency inhibits colon cancer development Carcinogenesis 2005;26:353-357.

24. Kitamura T, Itoh M, Noda T, et al. Combined effects of prostaglandin $\mathrm{E}$ receptor subtype $\mathrm{EP}_{1}$ and subtype $\mathrm{EP}_{4}$ antagonists on intestinal tumorigenesis in adenomatous polyposis coli gene knockout mice. Cancer Sci 2003;94:618-621.

25. Chamberlain SM, Rao SS. Safety evaluation of lubiprostone in the treatment of constipation and irritable bowel syndrome. Expert Opin Drug Saf 2012;11:841-850. 